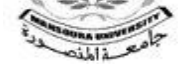

Mansoura University

Faculty of Tourism and Hotels

\title{
Developing The Performance of SeCurity Employees (Applied to 3 Star Hotels in AleXandria City)
}

\author{
Extract of $\mathrm{PhD}$ Thesis
}

\author{
By \\ Sayad Aly Aglan \\ PhD Researcher \\ Faculty of Tourism and Hotels - Mansoura University \\ Dr/Hanan Mohamed Lotfi \\ Ass. Prof of Hotel management- \\ Faculty of Hotel managment - \\ University of Alexandria in Matrouh \\ Prof/Wael Mahmoud Aziz \\ Prof of Hotel management- \\ Faculty of Tourism and Hotels - \\ Mansoura University
}


Developing The Performance of Security Employees

(Applied to 3 Star Hotels in Alexandria City) 


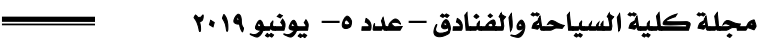

Developing The Performance of Security Employees (Applied to 3 Star Hotels in AleXandria City)

\author{
Sayad Aly Aglan ${ }^{1}$ \\ Dr/Hanan Mohamed Lotf $i^{2}$ \\ Prof/Wael Mahmoud Aziz ${ }^{3}$
}

\title{
Abstract
}

This study investigates the development performance of security line level staff in three star hotels in Alexandria city in order to protect the hotel guests ,hotel employees in addition to the hotel property by increasing the concept of safety and security to hotel security staff, handling modern security equipment and devices as well as conducting security plans to deal with Various critical situations such as tourism crimes, disasters and crises.

An analytical descriptive method was used to conduct the research. The questionnaire forms were designed and distributed to all employees of security departments in eight hotels of Alexandria city. The responses were $92.5 \%$. Statistical version 22 of the Social Sciences SPSS program has been used to discuss the phenomenon of the study and to analyze and calculate data from valid forms of analysis in addition to the use of Alpha Kronbach factor, frequencies, averages , standard deviations and percentage .

The most important results of the study had been proved that all three star hotels in Alexandria city dealing with stand alone walk through in metals, drugs and explosive detector guest gates In addition to the use of different types of fire extinguishers, with a shortage in using various up to date security equipment and devices, lack of training programs or conducting security plans to deal with various critical situations .The most important recommendations focused on the role of hotel management in applying the latest security equipment, activate advanced security training programs for security 
_ Developing The Performance of Security Employees

(Applied to 3 Star Hotels in Alexandria City)

personnel as well as recruiting high standard security calibres in terms of speaking English language and hold computer kills according to well designed security employee job description and finally establishing special units dealing with crises and disasters in each hotel.

Key Words: Security and Safety - Stand Alone Walk Through in Metal, Drugs and Explosive Detectors- Security Training Programs, Job description

\section{تطوير اداء العاهـين بالاهن بالتطبيـق على فنادق الثلاث نهوم بمدينه الاسكندروبة}

تهدف الدراسه الى تطوير اداء العاملين بقسم الامن فى فنادق الثلاث نجوم

بمدينه الاسكندريه و ذلك لحمايه نزلاء الفندق والعاملين به بالاضافه الى ممتلكات الفندق وذلك من خلال ترسيخ مفهوم الامن و السلامه المهنيه لدى العاملين بقسم الامن و استخدام الاجهزه الامنيه الحديثه و تنفيذ الخطط الامنيه للتعامل مـع مختلف المواقف الحرجه كالجرائم السياحيه و الكوارث و الازمات .

وفى اطار ذلك تم استخدام المنهج الوصفى التحليلى حيث تم تصميه و توزيع

استمارات الاستقصاء على جميع العاملين باقسام الامن فى ثمانى فنادق بمدينه

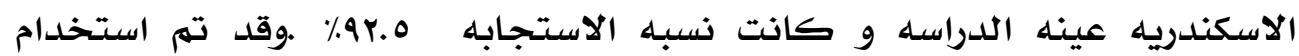

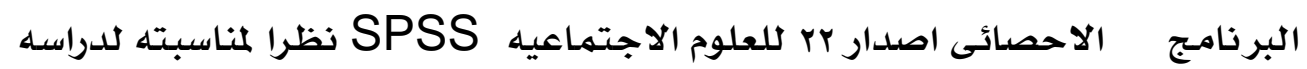
الظاهرة عينه الدراسه و لتحليل و حساب البيانات من الاستمارات الصالحه للتحليل بالاضافه الى استخدام معامل الفا كرونباخ و التكرارات و المتوسطات و الانحرافات المعياريه و النسب المئويه و قد انحصرت اهم النتائج فى التزام مسئولى الامن باستخدام بوابات الامن الكاشفه للمعادن و المتفجرات و المخدرات الخاصده بنزلاء الفندق بالاضافه الى استخدام مختلف انواع طفايات الحرائق مـع ضعف فى تواجد مختلف الاجهزه و 
مجلة كلية السياحة والفنادق - عدد ه- يونيو 19.

المعدات الامنيـه الحديثله بالاضدافه الى عدم وجود برامـج تدريبيـه و خطط امنيـه للتعامل مـع مختلف المواقف الحرجه التى يتعرض لها العاملين و النزلاء بالفندق . و كانت اهم التوصيات ضروره اتجاه الفنادق الى شراء احدث الاجهزه و المعدات الامنيه و تفعيل برامـج تدريبيـه متطوره لمسئولى الامن و ايجاد اليات مناسبـه لعمليات تعيين مسئولى الامن من حيث امتتلاكهم للهمهارة اللغويه الخاصده بالتحدث باللغه الانجليزيـه و معرفه الحاسب الالى و العمل على مراجعة التوصيف الوظيفى للعاملين بقسه الامن بصفه مستهمره بالاضافه الى انشاء وحدات خاصـه للتعامل مـع الازمات و الكوارث فى كل فندق.

\section{Introduction}

Tourism industry considered one of the most important industries in many countries, especially Egypt, because it is an excellent resource of foreign currency that contributes in supporting the national economy in addition to the added value of creating job opportunities for young people .According to the World Tourism Organization report 2019, Egypt tourists visitors reached in 2018 (11 million and 346 thousand ) spent 9 billion and 800 thousand dollars, and the spent average for each guest per day was 82.5 dollars(WTO Report ,2019).

The analysis of previous figures shows that the number of tourists is not commensurate with Egypt's tourism potential, but as a result of the youth revolution of January 11, 2011 and the absence of national security from the seen in general and hotels in particular led to the unwillingness of tourists to visit Egypt(Nasser2012,Mohamed,2012), which was reflected negatively on the occupancy percentages and hotel revenues in addition to the lack of security equipment in hotels, the absence of security employees training programs and the lack of security plans handling the threats of guests and employees. 
- Developing The Performance of Security Employees

(Applied to 3 Star Hotels in Alexandria City)

The aim of the research is to develop the performance of security personnel in terms of applying the concept of security and safety mechanisms to provide maximum protection to the hotel's guests, employees and property.

The Research hypotheses focused on the following points:

H.1 Absent of security and safety concept to hotel security staff

H.2 Absent of modern security equipment, devices, plans and security procedures in dealing with various critical situations

\section{Review of literature}

The term Security in general means the security of individual and dignity of human being in terms of fulfilling his physical and moral needs. This is achieved through the rule of law and the absence of threats in its various forms. It focuses on the survival and well-being of individuals and is divided into many types such as religious security, political security, economic security and tourism security.

The tourism security, is responsible for providing protection to tourists since their arrival to the country until their departure(Phellas2011,Spassford2006). Security research is facing many difficulties in terms of data collection and analysis, in addition to the lack of trained cadres to carry out field research. There are crimes committed by tourists such as theft, not paying services provided and false reports. Crimes against tourists such as crimes of violence, sexual harassment, counterfeiting credit cards, and the threat of bombings and terrorist acts(Jaswinder,2015). The tourism security had gained from other security branches some equipment, devices, security planes and procedures that can be used in hotels, most notably the guest gates of detectors for metals, drugs, explosives, surveillance cameras and Geographic Information System Security Support . 
The study discussed the relationship between the hotel security staff and the tourism police and antiquates in addition to the nature work of hotel security private companies in terms of advantages and disadvantages such as the absence of full loyalty of security company employees to hotel management, in addition to the organizational structure of staff in security department in terms of the availability of the security manager , assistant manager, supervisors of public areas, rooms corridors , back areas and the nature of the work of each employee according to job description and mechanisms of recruiting the employees(Chen 2014,harvy 2015,Mansfield,2006) .The personnel department, which is governed by internal and external factors related to the work environment such as employment policies, labour market, economic, social conditions, and exposure to the different training stages of identification of training needs and designing, evaluation training programs with an explanation of the most important methods used in training such as simulation, role playing, lectures, seminars, discussion , training on the job and external training.

The security personnel must know various risks (wong2011,yang2014,Hall 2004, lisele 2013)that are occurs to other employees in all divisions of the hotel such as rooms division : reception, telephone operators, housekeeping and food and beverage division: restaurants, room service, banquet and food production : hot food, cold food, baker and Pastry, stewarding and administrative division :receiving and storage, and personnel.

\section{Material and Methodology}

\section{2}

\section{Research aim and objectives}

The aim of the current study is to develop the Security employees performance concerning security awareness 
- Developing The Performance of Security Employees

,equipment usage and plans adopted. (SSPs) version 22 in the ( 8 ) Egyptian hotel sample. In particular, the specific objectives of the present study were pointed out as the following :

Identifying the awareness level of the SSPs in the hotel industry. Evaluating the actual usage (Performance) levels of the SSPs in the participated hotels.

Examining whether there are similarities or gaps between the awareness level and actual usage level of each SSPs.

Describing to what extent hotel respondents are implementing practical plans related to SSPs in the hotel operation.

Research conceptual framework

This study proposed a three-stage model for security and safety procedures implemented and practiced in hotels as following:

Research hypotheses

This study argued for the following hypotheses:

H1: The level of hotel security personnel awareness to SSPs is not affecting the SSPs usage.

$\mathrm{H} 2$ : The availability of SSPs practical plans and equipment usage is not

affecting the SSPs usage

\section{Research approach}

Research approach is concerned with how the research project will engage the use of theory (Saunders et al., 2009). (Finn et al. 2000) concluded that research needs theory as a framework for interpretation, while theory needs research to constantly review, modified, and challenge theoretical details. In this respect, researchers choose the best fit of different research approaches to their research aims. Generally, there are two research approaches; a deductive approach (testing theory) and 
an inductive approach (building theory) (Miller and Brewer, 2003; Teddlie and Tashakkori, 2006; Saunders et al., 2009).

The study objectives and questions revealed that it is primarily a descriptive- study. The study used quantitative approach, which included the developed questionnaire. Descriptive research describes and defines phenomenon or the problems as they exist. It is used to identify and obtain information on the characteristics of a specific problem or issue (Crotty, 2003). According to (Bryman and Bell, 2007) quantitative research refers to the use of structured, standard questions and pre-determined response options given in the form of a questionnaire to a number of respondents. It involves collecting and analyzing data that can be mathematically interpreted and analyzed (Collis and Hussey, 2009).The current study used deductive approach. (Saunders et al 2009) indicated that, deductive means reasoning from the particular to the general. If a causal relationship or link seems to be implied by a particular theory or case example, so it might be true in most of the cases.

\section{Data collection techniques}

The major final component in the research design is to find specific techniques of data collection and analysis. There are two basic sources of data: secondary data and primary data. Secondary data is the data that already exists such as books, documents and films (Collis and Hussey, 2009). Primary data is data collected specifically for the research project being undertaken by the researcher (Saunders et al., 2009).

The researcher uses the two methods of data collection. Secondary methods through searching in several database sources were used to conceptualize and operation the current study construct (SSPs).Research methodology plan included three main phases, which were: first, designing the study instrument; second, distribution of the questionnaire; third, 
- Developing The Performance of Security Employees

processing and analysis of the data. It is clear that the questionnaire were developed on the basis of the reviewed literature and the pilot study to quantify, supplement and complement the SSPs concept. A detailed description of the study phases will be provided in the following sections.

Statistical methods used in data collection

Phase 1: Designing questionnaire

\section{Identifying SSPs practices}

The first step in the current study required that SSPs practices in the hotel industry to be identified. The research process started with investigation of the relevant literature to extract recommendations and SSPs in this field. This process allowed the researcher to identify the SSPs related to the hotel operations. Based on this review, a list of SSPs was then identified.

\section{Reliability and validity tests}

Reliability, in its simplest definition, refers to a study being consistent and stable. A study that is internally consistent implies that the results are the same if another similar study would be carried out under similar conditions (Field, 2013).Cronbach's alpha test was used to determine internal consistency of the SSPs practices involved in the questionnaire. Table (1) shows Cronbach's alpha result by using SPSS program. The result showed that the Alpha coefficient of the scale items related to $\mathrm{SD}$ practices was 0.53 . The minimum value that is considered acceptable as an indication of reliability is 0.50 . Thus, this result indicates that the scale is reliable (Field, 2013).

Table 1: Cronbach's Alpha of reliability result

\begin{tabular}{|l|c|l|}
\hline \hline Items measure & No. of Items & Cronbach's Alpha \\
\hline SSPs awareness & 10 & 0.96 \\
\hline SSPs usage & 15 & 0.80 \\
\hline
\end{tabular}




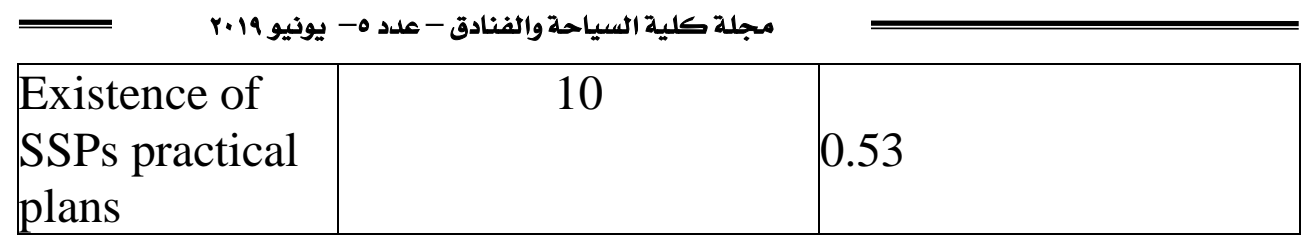

On the other hand, Validity determines if the research measures that which it was intended to (Hair et al., 2010). Two types of validity are applicable to the current study. Content validity and face validity. Content validity refers to the extent to which the questionnaires measure the actual concepts related to the topic. Face validity refers to the questions that are unambiguous to the respondents and therefore the gathered data will be valid (Field, 2013).

\section{The Study}

After the development of the initial set of items, the items purification stage was undertaken. The study survey was conducted using a questionnaire distributed with in 4 months from October 2018..to January 2019 ).

The responses obtained from the study were coded and analysed. Points raised and modifications recommended by hotel respondents were used to improve the structure of the questionnaire and the clarity of questions as well .In piloting, the reliability assessment is considered; scale reliability is the proportion of variance attributable to the true score of latent variables. It is a necessary condition for validity. It is to ensure that measures are free from error and therefore yield consistent results (Collis and Hussey, 2009).

Generally, Cronbach's alpha is the most commonly used tool for testing the reliability of a multi-scale measurement tool to assess whether all items are measuring the same thing (DeVellis, 2011). (Hair et al. 2010) and( Field, 2013,Hair 2010) mentioned that the value of alpha equal to 0.60 or above indicates that the items make a reliable and consistent set. Therefore, reliability analysis was first used to remove items with low item- 
Developing The Performance of Security Employees

(Applied to 3 Star Hotels in Alexandria City)

total correlations $(<0.3)$ or any items with cross correlations (Hair et al., 2006).Reliability of the items was assessed through using a questionnaire containing items obtained from the existing literature and results of the previous study phases. here were three methods to collect survey data: first, through internetmediated structural interviews; second, using on-line survey ; third, through postal surveys. Different data collection methods were implemented according to every type limitation as recommended by (Phellas et al., 2011).

The data-collection instrument in the current study is the questionnaire. A questionnaire is "a set of carefully designed questions given inexactly the same form to a group of people in order to collect data about some topic(s) in which the researcher is interested" (Sapsford and Jupp, 2006, ).

The designed questionnaire involved four sections as follows:

(1) The first section: A cover letter to explain the purpose of the survey, contact information, and general directions.

(2) The second section: Asking hotel security staff to what extent they are aware of security concept and its practices in the hotel operations.

(3) The third section: List of the 15 SSPs that are applicable in the hotel operations, to be assessed based on their actual equipment usage ,levels form, by using two 5-points Likert scale. Respondents were asked to rate each SSPs in terms of both the level of awareness and actual usage.

(4) The forth section: This section is related to understanding the respondents' perception about the SSPs practical plans implementation using 5-points Likert scale (1=Strongly Disagree 2=Disagree 3= Natural 4=Agree 5= Strongly Agree).

Phase 2: Questionnaire distribution

\section{- Determining the population and sampling}


مجلة كلية السياحة والفنادق - عدد ه- يونيو 19.r

While planning a study, it was important for the researcher to decide whether to investigate the total population or only a part of the population, in other words, deciding on a sample that represents the target population.

\section{The target population}

The target population of the current study was the security hotel staff working in the Egyptian hotels in Alexandria. Random sampling was chosen as the most appropriate sampling technique to achieve the study objectives .Table two, shows the total number of hotels in these three stated areas according to the Egyptian Hotel Association (EHA).

Table 2: The total number of hotels in Alexandria city :

Source:(EHA,2016)

\begin{tabular}{|c|c|}
\hline No & Hotel Name \\
\hline 1 & Adham Compound \\
\hline 2 & AIFFU Horizon Hotel \\
\hline 3 & Amoun Hotel \\
\hline 4 & Delta Hotel \\
\hline 5 & Desert Home \\
\hline 6 & Kaoud Sporting Hotel \\
\hline 7 & Lagoon Hotel \\
\hline 8 & San Giovani Hotel \\
& \\
\hline
\end{tabular}

\section{The sampling}

The sample size selected to be 54 security employees related to 8 hotels in Alexandria

\section{The questionnaire distributing procedures}

In the hospitality industry, the most commonly used tool of data collection is the survey or questionnaire (Sapsford and Jupp, 2006). Questionnaires are useful tools for investigating 
Developing The Performance of Security Employees

trends and measuring factors such as opinions. They are frequently used with success in management, marketing and consumer research. Questionnaires are extremely important as a measurement tool in applied social research (Saunders et al., 2009).

A total of 54 questionnaires were distributed to the staff of the sampled hotels (8 hotels). From the sample, 50 questionnaires were returned, with a response rate of $92.5 \%$. Thus, the valid questionnaires for analysis were 50 cases.

Phase 3: Data analysis

The data was entered into SPSS (version 22) data sheet and then all analyses were performed. The following statistical tests were used to achieve the current study objectives:

A.Analysis of scores mean (descriptive statistics), which was used to achieve the following tasks:

1. Evaluating the awareness level of the stated SSPs in the hotel sample.

2. Evaluating the actual plans and usage levels of the SSPs in hotels in Alexandria

B. Paired sample T- test, which was used to examine whether there are similarities or gaps between the awareness and actual usage level of each SSP.

C. Frequencies percentage analysis, which was used to describe to what extent hotels' managers are implementing SSPs practical plans in hotel operations.

\section{Results and Discussion}

The main findings

A total of 54 questionnaires were distributed to the sampled hotels ( 8 hotels). From the sample, 50 questionnaires were returned. Figure 1 shows the response rate which is $92.5 \%$. 
Respondent profile

Table ( 3 ): Respondents' characteristics.

\begin{tabular}{|c|c|c|c|}
\hline \multicolumn{2}{|c|}{ Respondent variables } & Frequency & Percent \\
\hline \multirow[t]{3}{*}{ Gender } & Male & 50 & 100.0 \\
\hline & Female & 0 & 0 \\
\hline & Total & 50 & 100.0 \\
\hline \multirow[t]{4}{*}{ Age } & $\begin{array}{l}\text { Under } 30 \text { years } \\
\text { old }\end{array}$ & 20 & 40.0 \\
\hline & $30-40$ & 16 & 32.0 \\
\hline & $40-50$ & 11 & 22.0 \\
\hline & $\begin{array}{l}\text { Over } 50 \text { years } \\
\text { old }\end{array}$ & 3 & 6.0 \\
\hline \multirow{3}{*}{$\begin{array}{l}\text { Education } \\
\text { level }\end{array}$} & High school & 15 & 30.0 \\
\hline & $\begin{array}{l}\text { Bachelor } \\
\text { degree }\end{array}$ & 35 & 70.0 \\
\hline & Total & 50 & 100.0 \\
\hline \multirow[t]{3}{*}{$\begin{array}{l}\text { Monthly } \\
\text { income }\end{array}$} & $\begin{array}{l}\text { less than } \\
1200 \mathrm{LE}\end{array}$ & 13 & 26.0 \\
\hline & $\begin{array}{l}1200-2000 \\
\text { LE }\end{array}$ & 37 & 74.0 \\
\hline & Total & 50 & 100.0 \\
\hline Sports & Football & 50 & 100.0 \\
\hline \multirow[t]{2}{*}{ Languages } & Arabic & 50 & 100.0 \\
\hline & English & 24 & 48.0 \\
\hline $\begin{array}{l}\text { Computer } \\
\text { skills }\end{array}$ & Internet & 50 & 100.0 \\
\hline
\end{tabular}

From the previous table, it is apparent that most of questionnaire respondents were all males. This might because that most females in the Egyptian hotels fear working in security department . Most of security officers about $40 \%$ are adults and their age level is below 30 years old which is a good indication to work conditions. It is also clear that $70 \%$ of them have a bachelor 
- Developing The Performance of Security Employees

(Applied to 3 Star Hotels in Alexandria City)

degree and nearly half of them (48\%) practice the English language when contacting the foreign guests which is a negative point and must be overcome. All of them recorded that they are excellent in some computer skills such as internet browsing regardless of other hotels applications such as Opera or point of sale - Micro.

Identifying the awareness level of the SSPs in the hotel cases

Table( 3 ) indicates the importance mean scores, as assessed by the hotel respondents.

Table( 4 ): Identifying the SSPS awareness level

\begin{tabular}{|l|l|c|c|c|}
\hline \multicolumn{2}{|c|}{ SSPs Awareness } & Mean & $\begin{array}{c}\text { Std. } \\
\text { Erro } \\
\text { r }\end{array}$ & $\begin{array}{c}\text { Std. } \\
\text { Deviatio } \\
\text { n }\end{array}$ \\
\hline P1 & $\begin{array}{l}\text { You are aware of Security Hotel } \\
\text { Concept }\end{array}$ & 3.92 & .114 & .804 \\
\hline P2 & $\begin{array}{l}\text { You are aware of safety and } \\
\text { security procedures in front } \\
\text { office and housekeeping } \\
\text { departments }\end{array}$ & 3.14 & .225 & 1.591 \\
\hline P3 & $\begin{array}{l}\text { You are aware of safety and } \\
\text { security procedures in food } \\
\text { production area and restaurants }\end{array}$ & 2.46 & .196 & 1.388 \\
\hline P4 & $\begin{array}{l}\text { You are aware of safety and } \\
\text { security procedures in steward } \\
\text { and storage areas }\end{array}$ & 2.70 & .229 & 1.619 \\
\hline P5 & $\begin{array}{l}\text { You are aware of safety and } \\
\text { security procedures in car } \\
\text { parking areas }\end{array}$ & 2.58 & .167 & 1.180 \\
\hline P6 & $\begin{array}{l}\text { You are aware of safety and } \\
\text { security procedures in handling } \\
\text { bomb threats }\end{array}$ & 1.70 & .129 & .909 \\
\hline P7 & $\begin{array}{l}\text { You are aware of safety and } \\
\text { You } 1.90\end{array}$ & .205 & 1.446 \\
\hline
\end{tabular}




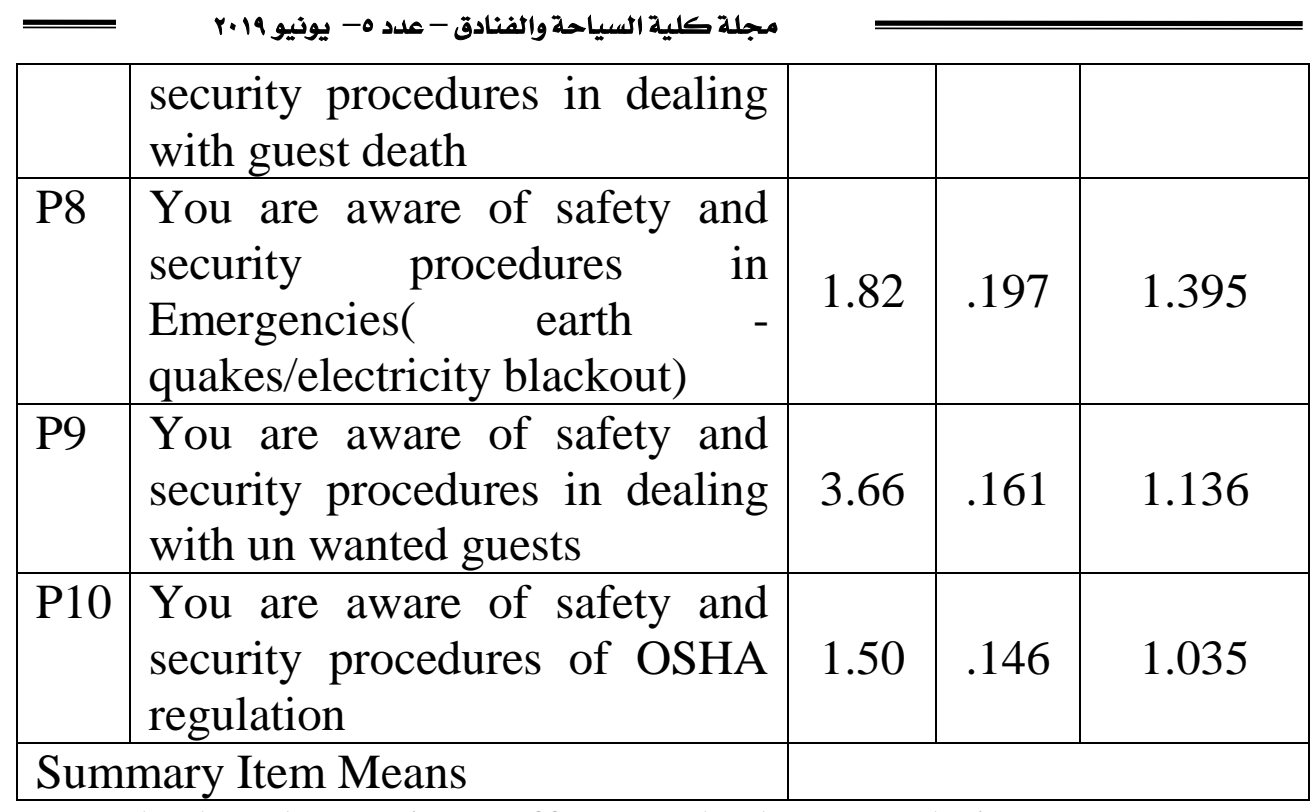

The hotel security staff was asked to rate their agreement with 10 security and safety procedures as highlighted in table 4 (P1:P10). Table (4) shows that the overall mean of awareness level is 2.538 which is near to choice 3 , which mean that their awareness level is still in its early stages .Specifically, the SSPs awareness degrees of agreement are highlighted in the following table.

Table( 5 ): SSPS awareness level frequencies

\begin{tabular}{|c|c|c|c|c|c|c|}
\hline \multirow{2}{*}{\multicolumn{2}{|c|}{ SSPs Awareness }} & \multicolumn{5}{|c|}{ Frequencies/ Percent } \\
\hline & & 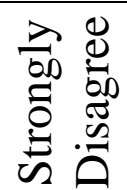 & 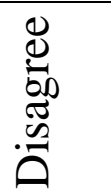 & $\begin{array}{l}\underset{\pi}{\overparen{T}} \\
\text { Z } \\
\text { Z }\end{array}$ & $\underbrace{0}_{0}$ & 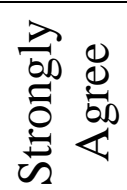 \\
\hline & $\begin{array}{lr}\text { You are } & \text { aware of } \\
\text { Security } & \text { Hotel } \\
\text { Concept } & \end{array}$ & $2 / 4$ & $1 / 2$ & $3 / 6$ & $37 / 74$ & $37 / 14$ \\
\hline $\mathrm{P} 2$ & $\begin{array}{l}\text { You are aware of } \\
\text { safety and } \\
\text { security }\end{array}$ & $15 / 30$ & $3 / 6$ & $3 / 6$ & $18 / 36$ & $11 / 22$ \\
\hline
\end{tabular}




\begin{tabular}{|c|c|c|c|c|c|c|}
\hline \multirow[t]{2}{*}{$=$} & \multicolumn{6}{|c|}{$\begin{array}{l}\text { Developing The Performance of Security Employees } \\
\text { (Applied to } 3 \text { Star Hotels in Alexandria City) }\end{array}$} \\
\hline & $\begin{array}{l}\text { procedures in } \\
\text { front office and } \\
\text { housekeeping } \\
\text { departments }\end{array}$ & & & & & \\
\hline P3 & $\begin{array}{l}\text { You are aware of } \\
\text { safety and } \\
\text { security } \\
\text { procedures in } \\
\text { food production } \\
\text { area } \\
\text { restaurants }\end{array}$ & $20 / 40$ & $5 / 10$ & $10 / 20$ & $12 / 24$ & $3 / 6$ \\
\hline $\mathrm{P} 4$ & $\begin{array}{l}\text { You are aware of } \\
\text { safety and } \\
\text { security } \\
\text { procedures in } \\
\text { steward and } \\
\text { storage areas }\end{array}$ & $22 / 44$ & $2 / 4$ & $1 / 2$ & $19 / 38$ & $6 / 12$ \\
\hline P5 & $\begin{array}{l}\text { You are aware of } \\
\text { safety and } \\
\text { security } \\
\text { procedures in car } \\
\text { parking areas }\end{array}$ & $12 / 24$ & $11 / 22$ & $15 / 30$ & $10 / 20$ & $2 / 4$ \\
\hline P6 & $\begin{array}{l}\text { You are aware of } \\
\text { safety and } \\
\text { security } \\
\text { procedures in } \\
\text { handling bomb } \\
\text { threats }\end{array}$ & $30 / 60$ & $5 / 10$ & $15 / 30$ & 0 & 0 \\
\hline P7 & \begin{tabular}{lr}
\multicolumn{2}{l}{ You are aware of } \\
safety \\
security \\
procedures \\
dealing in \\
\end{tabular} & $32 / 64$ & $7 / 14$ & $1 / 2$ & $4 / 8$ & $6 / 12$ \\
\hline
\end{tabular}




\begin{tabular}{|c|c|c|c|c|c|c|}
\hline & \multicolumn{3}{|c|}{ مجلة كلية السياحة والفنادق - عدد ه- يونيو 19.r } & \\
\hline & guest death & & & & & \\
\hline P8 & $\begin{array}{l}\text { You are aware of } \\
\text { safety and } \\
\text { security } \\
\text { procedures in } \\
\text { Emergencies( } \\
\text { earth - } \\
\text { quakes/electricity } \\
\text { blackout) }\end{array}$ & $35 / 70$ & $3 / 6$ & $2 / 4$ & $6 / 12$ & $4 / 8$ \\
\hline P9 & $\begin{array}{l}\text { You are aware of } \\
\text { safety and } \\
\text { security } \\
\text { procedures in } \\
\text { dealing with un } \\
\text { wanted guests }\end{array}$ & $5 / 10$ & $2 / 4$ & $7 / 14$ & $27 / 54$ & $9 / 18$ \\
\hline $\mathrm{P} 10$ & $\begin{array}{l}\text { You are aware of } \\
\text { safety and } \\
\text { security } \\
\text { procedures of } \\
\text { OSHA regulation }\end{array}$ & $40 / 80$ & 0 & $5 / 10$ & $5 / 10$ & 0 \\
\hline
\end{tabular}

From the above table (Table 4), the highest mean (3.92) was devoted to the practice of "You are aware of Security Hotel Concept" survey item as it shown in the following figure.

The next highest mean was for the practice of " You are aware of safety and security procedures in dealing with unwanted guests", (3.66) which is near the 4 Likert choice. It referred that the respondent is agreed with this procedure as shown in Figure 3.

As with the case of the lowest mean value was devoted to P10 which is 'You are aware of safety and security procedures of OSHA regulation'. Most respondents strongly disagree with 
- Developing The Performance of Security Employees

(Applied to 3 Star Hotels in Alexandria City)

this practice as the percent is $80 \%$. However, only $10 \%$ of respondents agreed with this practice.

3.1 Evaluating the actual usage levels of the SSPs in hotels

The possible range of actual usage started from 1.0 to 5.0, with 1.0 indicating rarely used, and 5.0 indicating extensively used. Table 4 indicates actual usage mean score, as assessed by hotels security staff.

Table ( 6 ) : Evaluating the actual usage levels of the SSPs in Hotels

\begin{tabular}{|l|l|c|c|c|}
\hline \multicolumn{2}{|c|}{ SSPs usage levels } & $\begin{array}{c}\text { Actual } \\
\text { usage } \\
\text { mean }\end{array}$ & $\begin{array}{c}\text { Std. } \\
\text { Error }\end{array}$ & $\begin{array}{c}\text { Std. } \\
\text { Deviatio } \\
\mathrm{n}\end{array}$ \\
\hline P1 & Usage of CCTV Cameras & 3.44 & 0.15 & 1.05 \\
\hline P2 & Usage of Feliometers sensors & 1.00 & 0.000 & 0.000 \\
\hline P3 & $\begin{array}{l}\text { Usage of Hand Held Metal } \\
\text { Detector }\end{array}$ & 1.66 & .168 & 1.189 \\
\hline P4 & $\begin{array}{l}\text { Usage of Stand a Lone Walk } \\
\text { Through in Metal Drugs and } \\
\text { Explosive Detectors }\end{array}$ & 4.10 & .043 & .303 \\
\hline P5 & $\begin{array}{l}\text { Usage of Computers with } \\
\text { Disease Program }\end{array}$ & 1.00 & 0.000 & 0.000 \\
\hline P6 & Usage of Wireless Phones & 1.30 & .129 & .909 \\
\hline P7 & Usage of Fire Extinguishers & 4.06 & .034 & .240 \\
\hline P8 & Usage of Guns & 1.00 & 0.000 & 0.000 \\
\hline P9 & Usage of 1st Aid Kits & 2.18 & .195 & 1.380 \\
\hline P10 & $\begin{array}{l}\text { Usage of Luggage X .Ray } \\
\text { Unit }\end{array}$ & 1.00 & 0.000 & 0.000 \\
\hline P11 & $\begin{array}{l}\text { Usage of Explosive Detector } \\
\text { Unit with Protected Clothes }\end{array}$ & 1.00 & 0.000 & 0.000 \\
\hline P12 & Car Parking Sensors & 1.00 & 0.000 & 0.000 \\
\hline
\end{tabular}




\begin{tabular}{|c|c|c|c|c|}
\hline & \multicolumn{4}{|l|}{ 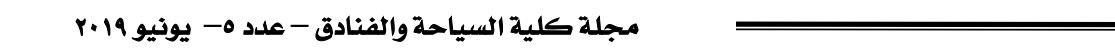 } \\
\hline & $\begin{array}{l}\text { Connected to Police } \\
\text { Station }\end{array}$ & & & \\
\hline P13 & Usage of G.I.S Technology & 1.00 & 0.000 & 0.000 \\
\hline P14 & $\begin{array}{l}\text { Usage of Finger/ Hand } \\
\text { Screen }\end{array}$ & 2.20 & 210 & 1.485 \\
\hline P15 & $\begin{array}{l}\text { Usage of Emergency lift } \\
\text { Phones }\end{array}$ & 1.00 & 0.000 & 0.000 \\
\hline \multicolumn{2}{|c|}{ Summary Item Means } & \multicolumn{3}{|c|}{2.706} \\
\hline
\end{tabular}

The hotel security staff was asked to rate their agreement with 15 security and safety procedures usage level as highlighted in table 6 (P1:P15). Table 6 shows that the overall mean of usage level is 2.706 which is near to choice 3 , which means that their usage level is not the optimum.

Specifically, the SSPs usage levels of agreement are highlighted in the following table.

Table (7) : Frequencies of the actual usage levels of the SSPs in Hotels

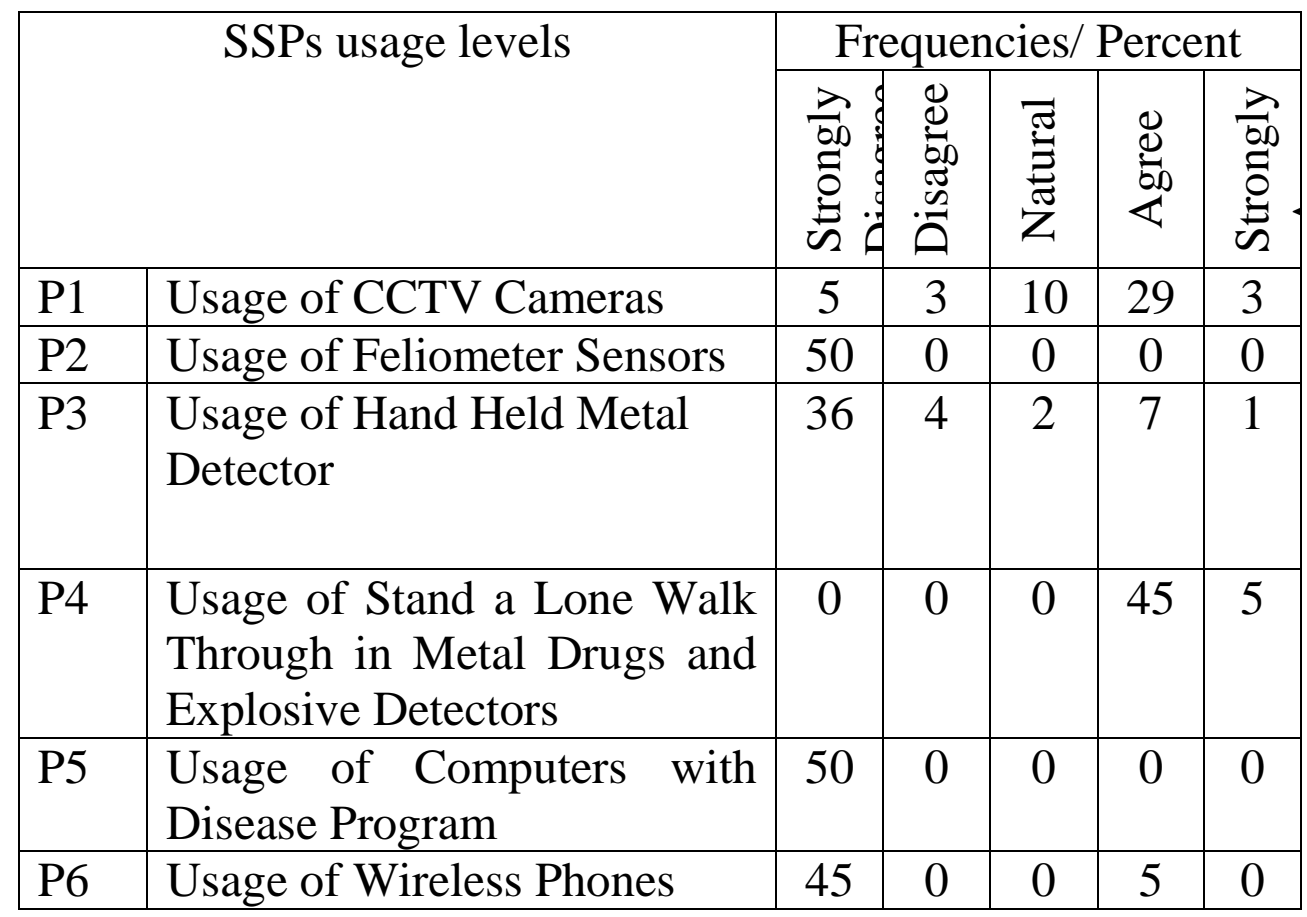




Developing The Performance of Security Employees
\begin{tabular}{|l|l|l|l|l|l|l|}
\hline (applied to 3 Star Hotels in Alexandria City) \\
\hline P7 & Usage of Fire Extinguishers & & 47 & & & 3 \\
\hline P8 & Usage of Guns & 50 & & & & \\
\hline P9 & Usage of 1st Aid Kits & 27 & 1 & 10 & 10 & 2 \\
\hline P10 & $\begin{array}{l}\text { Usage of Luggage X Ray } \\
\text { Unit }\end{array}$ & 50 & 0 & 0 & 0 & 0 \\
\hline P11 & $\begin{array}{l}\text { Usage of Explosive Detector } \\
\text { Unit with Protected Clothes }\end{array}$ & 50 & 0 & 0 & 0 & 0 \\
\hline P12 & $\begin{array}{l}\text { Car Parking Sensors } \\
\text { Connected to Police Station }\end{array}$ & 50 & 0 & 0 & 0 & 0 \\
\hline P13 & Usage of G.I.S Technology & 50 & 0 & 0 & 0 & 0 \\
\hline P14 & Usage of Finger/ Hand Screen & 30 & 0 & & 20 & 0 \\
\hline P15 & $\begin{array}{l}\text { Usage of Emergency lift } \\
\text { Phones } 50\end{array}$ & 0 & 0 & 0 & 0 \\
\hline
\end{tabular}

From the above table, the highest mean (3.92) was devoted to the practice of 'Usage of Stand a Lone Walk Through in Metal Drugs and Explosive Detectors' survey item as it shown in the following figure.

As with the case of the lowest mean value was devoted to (P5,10,11,12,13and 15). Take for example P15 which is ' usage of emergency lift phones '. Most respondents strongly disagree with this practice as the percent is $100 \%$.Describing to what extent hotel respondents are implementing practical plans related to SSPs in the hotel operation.

The last part of the study questionnaire was devoted to get the respondent perception regarding the existence of SSPs practical plans and its availability in the hotel operation. Table (8) shows the descriptive statistics related to this issue. 


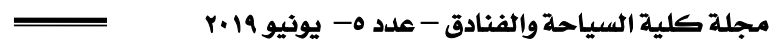

Table ( 8 ): Identifying the SSPS practical plans availability

\begin{tabular}{|c|c|c|c|c|c|}
\hline & \multirow[b]{2}{*}{$\stackrel{\Xi}{\Xi}$} & \multirow[b]{2}{*}{ 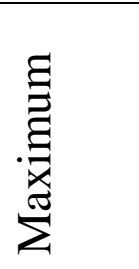 } & \multicolumn{2}{|c|}{ Mean } & \multirow[b]{2}{*}{ 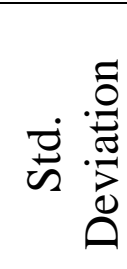 } \\
\hline & & & Statistic & $\begin{array}{l}\text { Std. } \\
\text { Error }\end{array}$ & \\
\hline $\begin{array}{l}\text { Existence of Co- } \\
\text { Operation plan } \\
\text { between Hotel } \\
\text { Management and } \\
\text { Private Security } \\
\text { Company }\end{array}$ & 1 & 4 & 3.76 & .116 & .822 \\
\hline $\begin{array}{l}\text { Existence of } \mathrm{Co}- \\
\text { Operation plan } \\
\text { between Hotel } \\
\text { Management and } \\
\text { State Police } \\
\text { Authority }\end{array}$ & 1 & 4 & 3.40 & .171 & 1.212 \\
\hline $\begin{array}{l}\text { Existence plan of } \\
\text { Hotel Disaster } \\
\text { Committee }\end{array}$ & 1 & 1 & 1.00 & 0.000 & 0.000 \\
\hline $\begin{array}{l}\text { Existence plan of } \\
\text { Employees } \\
\text { Suggestion Box }\end{array}$ & 1 & 1 & 1.00 & 0.000 & 0.000 \\
\hline $\begin{array}{l}\text { Existence Plan } \\
\text { Dealing with Crimes } \\
\text { Against (guest } \\
\text { violence ,sexual } \\
\text { harassment ,guest } \\
\text { hostage ,bomb } \\
\text { threats, counterfeit } \\
\text { credit cards }\end{array}$ & 1 & 1 & 1.00 & 0.000 & 0.000 \\
\hline
\end{tabular}




\begin{tabular}{|c|c|c|c|c|c|}
\hline \multicolumn{6}{|c|}{$\begin{array}{l}\text { Developing The Performance of Security Employees } \\
\text { (Applied to } 3 \text { Star Hotels in Alexandria City) }\end{array}$} \\
\hline ,gambling) & & & & & \\
\hline $\begin{array}{l}\text { Existence Plan } \\
\text { Dealing with Crimes } \\
\text { of guests ( robbery, } \\
\text { false reports ,guest } \\
\text { not paying } \\
\text { accommodation) }\end{array}$ & 1 & 2 & 1.22 & .059 & .418 \\
\hline $\begin{array}{l}\text { Existence plan } \\
\text { dealing with Hotel } \\
\text { Vans and Limousine }\end{array}$ & 1 & 2 & 1.60 & .070 & .495 \\
\hline $\begin{array}{l}\text { Existence plan } \\
\text { dealing with hotel } \\
\text { documents }\end{array}$ & 1 & 2 & 1.60 & .070 & .495 \\
\hline $\begin{array}{l}\text { Existence plan } \\
\text { dealing with } \\
\text { conducting Hotel } \\
\text { Security training } \\
\text { programs }\end{array}$ & 1 & 2 & 1.60 & .070 & .495 \\
\hline $\begin{array}{l}\text { Existence plan } \\
\text { dealing with } \\
\text { evacuation } \\
\text { procedures }\end{array}$ & 1 & 4 & 2.62 & .164 & 1.159 \\
\hline Summary items mean & & & 257 & & \\
\hline
\end{tabular}

From the previous table, it could be concluded that only two survey items : the existence of co-operation plan between hotel management and private security company and hotel management and state police authority have been get the highest mean values 3.8 and 3.4 respectively. This result is near from the scale choice 4 which refers the respondents agree with these items.

The following figure shows that $92 \%$ of respondent agreed with the availability of co-operation plan between hotel 
management and private security company as it appears in the following figure. Surprisingly, the lowest mean values of: Existence plan of Hotel Disaster Committee; Existence plan of Employees Suggestion Box; Existence Plan Dealing with Crimes Against were recorded 0.00 score of standard deviation. This confirmed that there is no differences among respondents related to these previously variables.

On the other hand, the hotel staff recorded the lowest mean values for these plans: hotel disaster committee ;employees suggestion box; plan dealing with crimes against (guest violence ,sexual harassment ,guest hostage ,bomb threats, counterfeit credit cards ,gambling); plan dealing with crimes of guests ( robbery, false reports, guest not paying accommodation); hotel vans and limousine; hotel documents; hotel security training programs; evacuation procedures.

Figure 8 shows an example of the lowest mean value (1.0) related to the availability of (Existence plan of Hotel Disaster Committee). It shows that all of them strongly disagreed with the availability of the hotel disaster committee plan.

Correlation between the research main factors

In this section, Person test (Table 9) was performed to check for the correlation between study main factors. Using SPSS transformation factor to compute a general means for the three main factors of: SSPs awareness; SSPs practical plans availability; SSPs usage guided for doing the correlation test correctly.

Table (9 ): Correlations between research factors

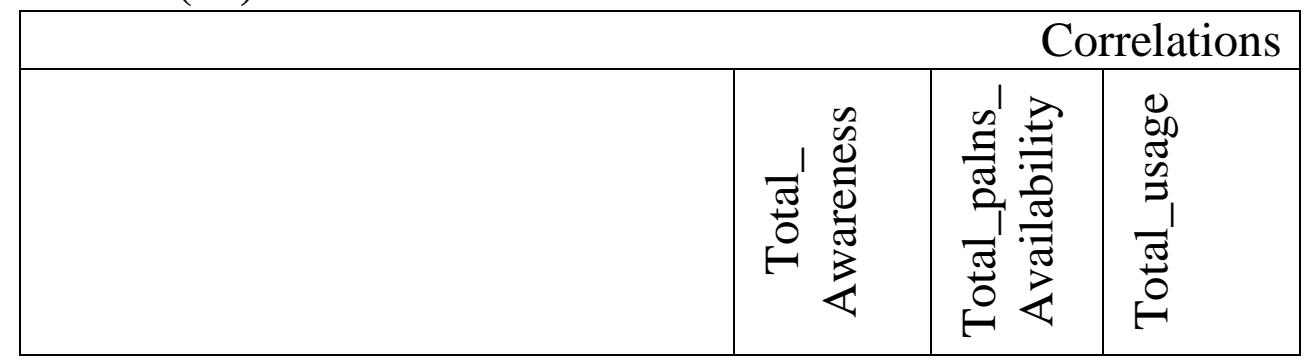




\begin{tabular}{|c|c|c|c|c|}
\hline \multicolumn{2}{|c|}{$\begin{array}{l}\text { Developing The Performance of Security Employees } \\
\text { (Applied to } 3 \text { Star Hotels in Alexandria City) }\end{array}$} & & & \\
\hline \multirow{4}{*}{$\begin{array}{r}\text { Total } \\
\text { Awareness }\end{array}$} & Pearson & 1 & .047 & $.964 * *$ \\
\hline & Correlation & & & \\
\hline & Sig. (2-tailed) & & .744 & .000 \\
\hline & $\mathrm{N}$ & 50 & 50 & 50 \\
\hline \multirow[t]{3}{*}{$\begin{array}{l}\text { Total_palns__ } \\
\text { Availability }\end{array}$} & $\begin{array}{r}\text { Pearson } \\
\text { Correlation }\end{array}$ & .047 & 1 & -.059 \\
\hline & Sig. (2-tailed) & .744 & & .683 \\
\hline & $\mathrm{N}$ & 50 & 50 & 50 \\
\hline \multirow[t]{3}{*}{ Total_usage } & $\begin{array}{r}\text { Pearson } \\
\text { Correlation }\end{array}$ & $.964 * *$ & -.059 & 1 \\
\hline & Sig. (2-tailed) & .000 & .683 & \\
\hline & $\mathrm{N}$ & 50 & 50 & 50 \\
\hline
\end{tabular}

It was found that there is high correlation value (0.96) between SSPs awareness variables and SSPs usage variables. Interestingly, this relationship is much more significant (0.000). However, Person test showed a converse relationship between SSPs plans availability variables and SSPs usage variables (-0.1). Testing the research hypotheses

Since the data is distributed in anon normality distribution due to small sample cases, it is not recommended to test the effects using ANOVA test. Therefore, one of the most popular non-parametric tests was performed to test for hypotheses. Kruskal-Wallis test (Table 10) was performed using the research three factors (SSPS awareness, usage, and practical plans availability). To adjust the Kruskal-Wallis test, the grouping factor of (education level) was selected as shown in the following table.

Table( 10 ): Kruskal-Wallis test

\section{Ranks}




\begin{tabular}{|c|c|c|c|}
\hline \multicolumn{2}{|c|}{ 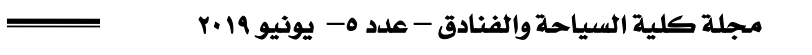 } & \multirow[b]{2}{*}{$\mathrm{N}$} & \multirow[b]{2}{*}{$\begin{array}{l}\text { Mean } \\
\text { Rank }\end{array}$} \\
\hline & $\begin{array}{l}\text { Education_ } \\
\text { level }\end{array}$ & & \\
\hline \multirow[t]{3}{*}{ Total_Awareness } & High school & 15 & 8.00 \\
\hline & $\begin{array}{l}\text { Bachelor } \\
\text { dgree }\end{array}$ & 35 & 33.00 \\
\hline & Total & 50 & \\
\hline \multirow[t]{3}{*}{ Total_palns_Availability } & High school & 15 & 13.87 \\
\hline & $\begin{array}{l}\text { Bachelor } \\
\text { dgree }\end{array}$ & 35 & 30.49 \\
\hline & Total & 50 & \\
\hline \multirow[t]{3}{*}{ Total_usage } & High school & 15 & 8.70 \\
\hline & $\begin{array}{l}\text { Bachelor } \\
\text { dgree }\end{array}$ & 35 & 32.70 \\
\hline & Total & 50 & \\
\hline
\end{tabular}

\begin{tabular}{|c|c|c|c|}
\hline \multicolumn{4}{|c|}{ Test Statisticsa,b } \\
\hline & $\begin{array}{c}\text { Total_Awar } \\
\text { eness }\end{array}$ & $\begin{array}{c}\text { Total_palns } \\
\text { _Availabilit } \\
\text { y }\end{array}$ & Total_usage \\
\hline $\begin{array}{l}\text { Chi- } \\
\text { Square }\end{array}$ & 30.979 & 14.345 & 28.952 \\
\hline $\mathrm{df}$ & 1 & 1 & 1 \\
\hline $\begin{array}{l}\text { Asymp. } \\
\text { Sig. }\end{array}$ & .000 & .000 & .000 \\
\hline \multicolumn{4}{|c|}{ a. Kruskal Wallis Test } \\
\hline \multicolumn{4}{|c|}{ b. Grouping Variable: Education_level } \\
\hline
\end{tabular}

Regarding to the first hypothesis of: H1: The level of hotel staff awareness to SSPs is not affecting the SSPs usage.

The Chi-Square significance level (Table 10) was significant. This means that there is correlation and direct effect of SSPs awareness level and SSPs usage. Thus, the null hypothesis is refuted and the alternative hypothesis is accepted. 
Developing The Performance of Security Employees

Likewise, the second hypothesis of H2: The availability of SSPS practical plans is not affecting the SSPs usage was refuted because Chi-Square significance level was significant. This means that there is correlation and direct effect of SSPs practical plans availability and SSPs usage.

\section{The Results :}

- Poor cooperation between the hotel management and the security

personnel of private security companies

- Poor cooperation between the hotel security personnel and the tourist and antiquities police

- The majority of security employees are males

- Poor of speaking English languages for Security employees in hotels

- Lack of knowledge for security employees in using hotel computer programs such as Opera for rooms and Micro for Food and Beverages

- Absence of up to date equipment and devices like special sensors to report any suspicious movements above or below the surface of the earth

or computers related to thermal cameras to detect guest diseases

- Weak use of wireless communication devices, fire sensors in parking places,

geographic information systems (GIS) for private protection

- Lack of mechanisms and plans to deal with various situations facing the guests and management of the hotel in relation to various topics such as sexual harassment, counterfeiting credit cards, thefts and hostage- taking and bomb threaten.

- Failure to implement training programs to raise the efficiency of security Hotel employees

- Lack awareness of special procedures of the OSHA in relation to 
health and occupational safety

\section{Recommendations :}

- Establish effective communication channels between hotel management and employees of private security companies through periodic meetings to discuss various problems affecting the operation.

-Establish effective communication channels between the hotel management and police officers of tourism and archeology through periodic meetings to discuss various problems affecting the operation .

-Expand female Recruitment in security departments in all hotels.

-Conduct training courses for security employees in English language and computer skills regarding opera program for the rooms division and micro program for food and beverage division to help theft preventing.

-Expand the purchase of the latest equipment and security tools to protect hotel guests, staff and hotel assets, especially the GIS for securing the sites of the hotel.

-Adopt security plans through establishing a crisis and disaster units to deal with various critical situations faced by the guests, staff and management of the hotel, such as sexual harassment, various types of thefts, credit card fraud taking hostages and bomb threats.

-Holding several training courses in the field occupational safety in all sections of the hotel whether in the rooms sector, food and beverage sector and administrative sector

${ }^{1} \mathrm{PhD}$ Researcher Faculty of Tourism and Hotels - Mansoura University

${ }^{2}$ Ass. Prof of Hotel management- Faculty of Hotel managment - University of Alexandria in Matrouh

${ }^{3}$ Prof of Hotel management- Faculty of Tourism and Hotels - Mansoura University 


\section{References :}

- Brymen ,and Bell ,(2007),Business Methods , Oxford university press,pp23:42

- Chen, KY (2014) Improving importance-performance analysis: The role of the zone of tolerance and competitor performance. The case of Taiwan's hot spring hotels. Tourism Management,pp50:61

- Collis, J and Hussey MR (2009), Business Research : Practiced Guide for Undergraduate and Postgraduate Students , Palgrave Macmillan,pp53:57

- Crotty ,M(2003) The Foundations of Social Research : Meaning and Perspective in Research Process ,sage publications, pp30:40

- Devellis, R.F (2011), Scale Development : Theory and Application ,sage publication, pp60:70

- EHC (2016) Egyptian Hotels Guide ,Egyptian Hotel Chamber, ETF.

- Field, A (2013) Discovering Statistics Using IBM SPSS Statistics , Sage ,London,pp135:155

- Finn , M., Elliott- White , $\mathrm{m}$ and Walton ,M (2000), Tourism and Leisure Research Methods, Longman ,pp75:98

- Harvey Burstein (2015) Hotel and Motel Los Prevention,pp120:134

-Hall C, Timothy D, Duval D (2004) Security and tourism:

Towards a new understanding? Journal of Travel and Tourism Marketing, vol 2,pp 66:98

-Hair, J.F, black, W, Babin ,B.(2010), Multivariate Data Analysis: A Global Perspective , Pearson prentice hall , upper saddle river ,pp142:166 
- Jaswinder Singh(2015) Safety and Security Concerns in Hospitality Industry ,International Journal of Management and Competence Innovations, vol 2,issue 5,pp 34:50

-Lisle D (2013) Frontline leisure: Securitizing tourism in the War on Terror, Security dialogue. pp 99:111

- Mohammad A, Jones E, Dawood A, Sayed HA (2012) The Impact of the Egyptian political events during 2011 on hotel occupancy in Cairo, Journal of Tourism Research and Hospitality , vol1,pp55:61

- Martilla J, James J (1977) Importance-performance Analysis , Journal of Marketing, vol 2, pp 166:180

-Mansfield Y, Pizam A (2006) Toward a Theory of Tourism Security. pp.99:110.

-Miller ,R.L and Brewer, and Brewer, J.D (2003), The AZ of social research : A dictionary of key Social Science Research Concepts ,sage ,London pp.150:153.

- Nassar MA (2012) Political Unrest Costs Egyptian Tourism Dearly: An Ethnographical Study, International Business Research.pp140:160

- Phellas, C.N.,Bloch,a and Seale, C (2011) Structured Methods ; Interviews ,Questionnaires and Observation ,Research society and Culture London, Sage publication,pp132:133

- Sapsford ,R.and Jupp,(2015),Data Collection and Analysis ,Sage London,pp163:167

- Saunders,M,Lewis,p. and Thornhill ,A (2009) Research Methods for Business Stewarts,Financial Times Prentice hall ,England pp.65:80

-Teddlie, C.and Tashakkoric, A (2006) A General Typology of Research Designs pp .66:96

- Wong M, Hideki N, George P (2011) The Use of ImportancePerformance Analysis (IPA) in Evaluating Japan's E- 
government Services. Journal of Theoretical and Applied Electronic Commerce Research,vol1,pp190:193

- Yang ECL, Nair V (2014) Tourism at risk: A review of risk and perceived risk in tourism. Asia-Pacific Journal of Innovation in Hospitality and Tourism, vol 2 pp.66:70 Reports

World Tourism Organization Report 2019 